\title{
Leaving the Stag Hunt: The Conservative Denial of Collective Action Problems
}

Robert J. Lacey

\begin{abstract}
I argue in this essay that today's conservatives have proven themselves radical-i.e., completely out of step with the history of western political thought-in their refusal to acknowledge the existence of collective action problems and the role government must often play to solve them.
\end{abstract}

Key words: Financial crisis, Obama, US economy, collective action

I

$\mathrm{D}$ ominique Strauss-Kahn, the scandal-ridden former director of the International Monetary Fund, tells a revealing story in the Oscarwinning documentary Inside Job about a dinner party hosted in the fall of 2008 by then-Secretary of the Treasury Henry Paulson. In attendance were a number of officials and CEOs from the biggest financial institutions in the US, and the financial crisis was the obvious topic of conversation. In a staggering moment of honesty, perhaps inspired by sheer panic, all of these men admitted that they were in part responsible for the crisis. Then, according to Strauss-Kahn, they turned to Paulson and said, "You should regulate more because we're all too greedy; we can't avoid it. The only way to avoid this is to have more regulation." 1

Over a year after the initial fears of widespread financial implosion had subsided, President Obama tried to make good on the suggestion made at Paulson's dinner party. As expected, Obama faced hostility from Wall Street and the Republicans when he championed and eventually passed the Consumer Financial Protection Act in 2010. But, in that unguarded moment at Paulson's party, the bank officials revealed not only their own culpability for the crisis but also their understanding of the system that allowed-even encouragedtheir reckless behavior. A return to regulation, they conceded, was the only way to prevent banks and other institutions from acting in a way that was immensely profitable in the short term, but disastrous for the financial system as a whole.

${ }^{1}$ Charles Ferguson, Inside Job (Sony Pictures Classics, 2010). 
Viewers of Inside Job learn that deregulation led to the development of securitization, a system that allows lenders to sell trillions of dollars in mortgages and other loans to investors willing to buy them. Investment banks are the middlemen who facilitate this process, combining thousands of loans to create complex derivatives called collaterized debt obligations (CDOs) and then selling them to investors around the world. As Barney Frank explains in the film, the problem with securitization is that "the people who make the loan are no longer at risk if there is a failure to repay." 2 Because lenders did not bear the risk, they no longer had the incentive to be cautious. After all, if borrowers failed to make their payments on time and defaulted on their mortgages, the investors who purchased the loan were the ones stuck with the loss. Knowing that they could immediately sell loans to investors, lenders no longer cared whether a borrower could repay and had an incentive to make as many loans as possible, no matter how risky they may have been. The investment banks, whose profits were based on the number of CDOs they sold, had the same perverse incentive. Quantity had replaced quality in the real estate loan industry.

The tragedy of securitization is that it allowed lenders and investment banks to transfer risk to woefully uninformed investors. Of course, if the market had been working, investment banks would not have been able to sell CDOs so easily. Knowing that these complex bundles of risky loans were bad investments, most investors would have steered clear of them. But investors didn't know, thanks to an unchecked conflict of interest. The rating agencies, paid by the investment banks, gave CDOs the highest investment grades, including even AAA ratings. The securitization food chain-linking borrowers, lenders, bankers, credit agencies, and investors — was infected with the blight of misinformation.

Now we all know that the crash was inevitable because the entire system rested on a fatal conceit - that real estate would forever increase in value and thus was a safe bet for everyone involved, including both borrowers who were encouraged to take out sub-prime mortgages and investors who bought those mortgages in large bundles. In September 2008, the conceit was exposed as mass delusion when the economic bubble burst and nearly brought about the second Great Depression. The take-away for viewers of the film is clear: the absence of government regulation or oversight of some kind made this crisis possible, if not inevitable.

Despite its well-deserved accolades for explaining the causes of the recent financial crisis, Inside Job sometimes fails to inform and educate, particularly when it draws viewers' attention away from the systemic causes of the crisis and toward the mischief of individuals on Wall Street. Perhaps the most unfortunate distraction is the title of the film, which suggests organized criminality and conspiracy. Inside Job might be an appropriate title for a Michael Moore documentary, but the main virtue of this film, directed by Charles Ferguson, was its deft framing of the financial crisis as a systemic problem 
caused by deregulation. The film is at its best when it shows that the crisis is the result of what social scientists call a collective action problem.

A collective action problem can be defined as a situation where individually rational behavior yields collectively irrational (less than optimal) outcomes. Political and social theorists have long recognized the tension between individual freedom and the general welfare. A society composed of individuals serving only their own interests, even if doing so within the law and without directly violating the rights of others, can produce general results from which everyone suffers. The many actors involved in the crisis-including borrowers, lenders, and bankers - were not villains pulling an "inside job" on the financial system; they were rational individuals who clearly saw the incentive structure before them and followed their own interests accordingly. The result of their individually rational behavior was a collective disaster.

It is hardly an exaggeration to suggest that the conflict between conservatives and liberals in America today arises in large part from their opposing views about collective action problems. Conservatives generally see a natural agreement between private and general interests to which government poses the gravest threat. In short, they believe that government is the cause of collective action problems. Liberals, on the other hand, find that government often represents the best chance at a solution to many collective action problems. The reason for this divergence is that conservatives only recognize a unique kind of collective action problem called moral hazard.

Moral hazard is the idea that individuals will behave more recklessly or wastefully when given some kind of insurance that covers the costs. Broadly construed, insurance can be understood as any form of protection or coverage that alters a person's behavior. For example, it has often been asserted, though never substantiated, that Volvo drivers are more likely to get in accidents. It may be the case that driving a Volvo, by reputation the safest and sturdiest car on the road, is a kind of insurance that creates a moral hazard, giving people a sense of security that makes them more careless behind the wheel. (But it's also possible that self-selection would explain such a finding - that is, people who buy Volvos are worse drivers.)

Supporters of the Tea Party have invoked moral hazard in their opposition to the bank bailout in late 2008: knowing that the US government is there to help them should anything go wrong, the big financial institutions will continue to make the kinds of risky investments that led to the financial crisis in the first place. ${ }^{3}$ The strong likelihood of another government bailout can be seen as a form of insurance that will encourage further reckless behavior on Wall Street.

3 Tea Party darling Michele Bachmann wrote the following about the bank bailout: "The moral hazard this bill creates will ripple through the entire financial marketplace. Providing banks with a bailout guarantee will perpetuate a cycle of irresponsibility, shielding creditors from taking the fall for making risky decisions and forcing taxpayers to ante up again and again." See Michele Bachmann, "Giving More Power Where Power Is Not Due," in the Star Tribune (10 December 2009), <http://www.startribune.com/opinion/79012857.html>. 
In general, conservatives are quick to identify moral hazards created by government. They oppose a single-payer health care system, for example, because they believe it will encourage the frivolous use of health care services and drive up costs. Even though a surfeit of evidence shows that moral hazard is not a major cause of rising health care costs and that single-payer and other kinds of universal health care systems are actually more efficient, conservatives insist on seeing the issue through this particular lens. In their view, it just has to be the case that when government intervenes to make a service free or affordable, people will start using it far more frequently. Meanwhile, the facts support what common sense tells us: receiving health care is so onerous to most people that, even if told the visits will be free, they won't start running to the doctor every time they get a sniffle. ${ }^{4}$

Empirical evidence notwithstanding, it should not come as a surprise when conservatives refuse to remove their moral hazard lens. Their opposition to big and intrusive government in the area of social policy has been informed by moral hazard for quite some time. As they see it, moral hazard can explain why people receiving any kind of government benefit—such as unemployment insurance, food stamps, or welfare-might be less motivated to return to the workforce and contribute fully to the free market economy. By ensuring that individuals will not suffer the consequences of their actions, the generous welfare state gives them the incentive to remain careless and lazy.

The conservative critique is not completely devoid of merit. In the wake of the Great Society the welfare state had undoubtedly produced perverse incentives that discouraged work. The Personal Responsibility and Work Opportunity Reconciliation Act of 1996, though hardly an unmitigated success, was an attempt to reinvigorate the incentive to work among welfare recipients. For more than two decades, liberals have been mindful of the conservative concern about government-sponsored moral hazard. Lest we forget, it was a moderately liberal Democrat by the name of Bill Clinton who promised welfare reform during his presidential campaign and got it passed by the end of his first term.

The problem is that conservatives see moral hazard in every government activity related to social and economic policy. They simply refuse to discriminate between programs that work and those that do not. Because conservatives believe government almost always harms the general welfare, they propose reducing its size as much as possible, slashing and cutting with extreme prejudice. But, as President Obama has said in recent months, a more sensible course of action for lawmakers with concerns about wasteful spending is not to butcher government with a machete, but to operate on it with a scalpel.

Liberals have a more balanced view of government intervention because they are also concerned with a type of collective action problem that conservatives completely ignore: problems of cooperation. As political

4 See Malcolm Gladwell, "The Moral-Hazard Myth," in The New Yorker (29 October 2005), < http://www.newyorker.com/archive/2005/08/29/050829fa_fact>. 
thinkers in the Western tradition have understood for many centuries, collective action problems often arise when government is nowhere to be seen, allowing free and rational individuals to act in ways that, though not directly harmful to others, bring distress and suffering to their community.

For example, liberals tend to favor single-payer health insurance because they believe it will correct for the problems of cooperation in our current system. After Obama's health care reform of 2010 takes full effect, assuming it is not repealed by Congress or struck down by the Supreme Court, there will still be about 16 million people without health insurance in America. Even if most of these people do not choose to go without health insurance but are priced out of the private market, they can be understood as free-riders. The problem with free-riders (or the uninsured) in a health care system is that they create inefficiencies. This is because they rarely get preventive care or routine treatment when they have minor illnesses. For most uninsured people, it is too expensive to pay for doctor visits and medicine out of pocket. This places the uninsured population at greater risk of becoming seriously ill, at which point they will be rushed to the emergency room and given expensive treatment to keep them alive. Because they are not able to pay their steep medical bills, the rest of us incur the cost with higher premiums or taxes. If everyone were insured, the system would be more efficient and thus costs would not be as high. Unfortunately, as things stand, it is still rational (and unavoidable) for millions of people to go without health insurance and avoid treatment until catastrophe strikes. The end result is the most costly and inefficient health care system in the world. 5

Liberals can point to a number of other inefficiencies with the current health insurance model in the United States. While conservatives believe that the private sector is always more efficient than government could ever be, liberals know that administrative costs are much higher when private insurers expend so much time and energy competing for policy holders, especially healthy ones, and finding ways to deny policy holders coverage when they file a medical claim. It is eminently rational for each insurer to engage in these activities, but the significant costs imposed on the system are collectively irrational. Unsurprisingly, the administrative costs of health care are far higher in the United States than in any comparable country with universal coverage. ${ }^{6}$

5 The United States spent more on health care per capita in $2008(\$ 7,164)$ than any other country in the world, and its health care costs as a percentage of GDP in 2008 (15.2) were also the highest in the world. See World Health Organization, World Health Statistics 2011, <http://www.who.int/whosis/whostat/2011/en/index.html>. Also see Paul Krugman, The Conscience of a Liberal (New York: W. W. Norton \& Co., 2007), 214-243.

6 In 1999, for example, the United States spent $\$ 1,059$ per capita on health administration expenditures, while Canada spent only $\$ 307$. Administration accounted for 31.0 percent of health care costs in the U.S. and 16.7 percent in Canada. See Steffie Woolhandler, Terry Campbell, and David Himmelstein, "Costs of Health Care Administration in the United States and Canada," in The New England Journal of Medicine 349:8 (21 August 2003). The authors conclude that the U.S. would save significantly on administrative costs if it adopted a singlepayer system. 
There is a particular kind of cooperation problem to which liberals pay careful attention: externalities. An externality can be defined as the unintended consequences of a private transaction from which a third party suffers. The American philosopher John Dewey (1859-1952) argued that this third party becomes a "public" if it suffers from a private transaction "to such an extent that it is deemed necessary to have those consequences systematically cared for" by the government. ${ }^{7}$ Those of us who choke on the pollutants billowing from nearby factories, for example, constitute a "public" which asks for government regulation of the industries at fault. These industries do not want to contaminate our air; it is merely the unfortunate byproduct of doing business. Because of the costs involved, it is not rational for these industries to act in an environmentally responsible manner. As a result, government must step in to ensure that companies will do the irrational thing (i.e., eliminate or reduce their pollution output) and bring about a collectively rational outcome (i.e., a cleaner and healthier world).

\section{II}

For all their talk about preserving tradition and holding sacred the ideas and values inherited from our revered ancestors, modern conservatives are in fact quite radical. For many centuries social theorists have been searching for ways to solve various collective action problems. Political science has focused on the constructive role that government can play to ensure cooperation among self-interested individuals who, left to their own devices, would never honor their agreements with others, even though they would benefit in the long run from doing so. Yet conservatives today act as if this idea never existed. In their dismissal of problems of cooperation, conservatives ignore a central (and ubiquitous) concept in the Western tradition which political thinkers on both the right and the left have accepted for quite some time.

From the right side of the political spectrum, English philosopher Thomas Hobbes (1588-1679) argued in Leviathan that human beings living in the state of nature - that is, without stable government-are in a constant state of war. Without a strong government imposing law and order, human beings pursue their self-interest relentlessly, leading to a precarious existence of mutual mistrust and regular eruptions of violence. In a world where human beings are not guided or restrained by an innate sense of justice or morality, said Hobbes, it is quite rational-indeed, within one's rights— to initiate warfare against others for either gain, security, or reputation. The problem is that if each person follows this right of nature, the collective result is a "nasty, brutish, and short" life for everyone. ${ }^{8}$ For this reason, said Hobbes, the Law of Nature instructs us to seek peace whenever we can. But there's a catch: the

15-16.

7 John Dewey, The Public and Its Problems (New York: Henry Holt and Company, 1927),

${ }^{8}$ Thomas Hobbes, Leviathan (New York: Penguin Classics, 1985), 186. 


\section{LEAVING THE STAG HUNT}

sensible person knows that seeking peace in the state of nature is mere folly, for there is no reason to trust that others will lay down their arms as well. Only when an awe-inspiring sovereign makes people fear the consequences of not seeking peace more than they fear their fellow men will people heed the Law of Nature and cooperate with others. In other words, Hobbes saw the state of nature as a collective action problem that only a powerful autocrat could solve.

A very different thinker who also viewed politics through the lens of collective action was Jean-Jacques Rousseau (1712-1778), an enemy of autocracy and a supporter of direct democracy. Often credited for inspiring the French Revolution, Rousseau believed that only after people enter civilization do collective action problems emerge. In the state of nature, prior to the tragic fall of man into his corrupted state of civilization, human beings led solitary and peaceful lives that did not require working with others. But with the accoutrements of civilization-language, tools, property, and the division of labor-came problems of cooperation. In the Discourse on the Origin of Inequality Rousseau famously drew on the parable of the stag hunt to highlight the perennial conflict between private and general interest. In his description, a successful stag hunt requires cooperation from everyone involved. The strategy is to form a circle around the stag. If any of the hunters abandons his assigned post, the deer will get away and the entire hunting party will go hungry. Unfortunately, it is quite likely that one of the hunters will abandon this mutual undertaking the moment he sees within his reach a hare-easier prey that a person can catch on his own. Aware that others in the group may undermine this fragile enterprise in the pursuit of selfinterest, each hunter has a strong incentive to search for smaller game and to violate the agreement when the opportunity arises. While cooperation would yield far better results for all, breaking from the group is the individually rational course of action.

Like Hobbes, Rousseau believed that government existed to ensure cooperation in such cases. But Rousseau did not think that cooperation required the concentration of power in the hands of a single sovereign. Instead, he argued that democracy could promote cooperation far more effectively. This is because democracies do a better job of producing laws that reflect the general interest. It is important to add that, despite the diffusion of power in a democracy, its government will never hesitate to use coercion when necessary. The citizen who insists on defying the general will, said Rousseau, must be "forced to be free."

Though they differ greatly in their views about the distribution of power, Hobbes (the authoritarian) and Rousseau (the democrat) agree that government represents the answer to collective action problems. In addition to these two thinkers, the canon of Western political thought includes countless others who accept the premise that government interference of some kind is often required to make recalcitrant individuals cooperate with others in

9 Jean-Jacques Rousseau, The Basic Political Writings (Indianapolis: Hackett Publishing Company, 1987), 150. 
their community. More recently, the study of collective action problems has become more systematic, even scientific. Rational choice theorists, for example, have used the prisoners' dilemma and other models to formalize in mathematical terms the rational basis for violating agreements. This is what the mathematicians and formal theorists have revealed: While it is true that everyone suffers from the lack of cooperation, it is often more rational for an individual to violate agreements than to risk the dire consequences of sticking to them.

Perhaps the most important thinker of recent years to comment on the issue of collective action problems is Mancur Olson (1932-1998), an economist who taught for many years at the University of Maryland. His first and most influential book, The Logic of Collective Action, is required reading for every doctoral student in political science today-and for good reason. Olson made an essential contribution to the study of groups on which social scientists from many disciplines, particularly political scientists, have drawn. $\mathrm{He}$ challenged the conventional wisdom accepted by most American political scientists at the time that groups will necessarily act to further their goals or interests. Before Olson, political scientists assumed that, if members of a group stand to benefit from a particular collective outcome, each person in that group would voluntarily do what is necessary to achieve that objective. As a result, the group would do everything it could to advance its interests. After Olson, political scientists opened their eyes to the reality, illuminated both theoretically and empirically, that individual and collective rationality do not always converge. Even when all of the individuals in a large group "are rational and self-interested, and would gain if, as a group, they acted to achieve their common interest or objective," said Olson, "they will still not voluntarily act to achieve that common or group interest." 10

Why is this so? The explanation is often referred to as the free-rider problem. Rational individuals see all too well that they can still enjoy the benefits of collective action while they stay home and let everyone else in the group do the work. Even if someone stands to benefit immensely from a certain collective good, it is rational to take a free ride, to avoid paying the price. After all, some other suckers will ante up. The problem is that because most individuals make the same calculation, the group will never cohere and pursue its interests. Olson concludes that free and self-interested individuals will only pursue what is in their common interest if they are forced-or given strong incentives - to do so. Of course Olson was not saying anything new. Readers of Hobbes and Rousseau were already familiar with his argument. He was merely updating an old idea and introducing it to his largely American audience, whose naive understanding of democracy seemed to be derived from classical pluralism. James Madison, perhaps the original pluralist, simply

${ }^{10}$ Mancur Olson, The Logic of Collective Action (Cambridge, MA: Harvard University Press, 1965), 2. 
assumed that people who share a common interest would form a wellorganized group in order to influence government policy. ${ }^{11}$

\section{III}

Students of politics, if at all familiar with the history of Western political thought, are in no position to deny the prevalence of collective action problems arising from the relentless pursuit of self-interest. Nor can they deny the important role that governments play in solving these problems, reconciling private interests with the general welfare. Yet this is exactly what conservatives in the United States are doing today. Despite overwhelming evidence to the contrary, they operate under the assumption that private and general interests are naturally in harmony-that when individuals are free to pursue their own interests short of violating the rights of others, society as a whole automatically benefits.

The idea that the individual pursuit of happiness is always harmonious with collective outcomes does have intellectual roots and can be found most readily in the works of Friedrich Hayek (1899-1992), the Austrian-born philosopher and economist who won the Nobel Prize in 1974. Known for his defense of classical liberalism, Hayek has enjoyed a renaissance in recent years due to the great enthusiasm for his work among Tea Party activists. Recent champions of Hayek include conservative pundits Glenn Beck and John Stossel, both of whom have spoken at length on air about Hayekian principles. It's worth noting that Hayek has attracted supporters outside academia for quite some time. Attempts at popularizing his work date back to the 1940 s when Reader's Digest published a condensed and more accessible version of his most famous book, The Road to Serfdom. In this landmark work Hayek warned that central economic planning by the government will push society down a slippery slope at the bottom of which tyranny and misery await. Hayek was one of the first thinkers to understand that unrestrained government intrusion in private (especially economic) life is the essential characteristic of all totalitarian regimes, whether they fall on the ideological left or right. The Nazis and the Soviets may have hated each other, but they shared a chilling enthusiasm for the omnipresent state.

The enduring popularity of The Road to Serfdom has turned Hayek into a poster child for the conservative denial of collective action problems, even though he disavowed the conservative label and always considered himself a part of the classical liberal tradition. Central to his classical liberal thought is "spontaneous order," the term Hayek used for "those unintended patterns and regularities, which we find to exist in human society." He saw spontaneous order as a system or aggregate structure that is "due to human action but not to

11 See James Madison, "No. 10," in the Federalist Papers (New York: Signet Classics, 
human design." 12 This system or structure is the unintended consequence of free individuals acting solely out of self-interest. Drawing on his understanding of markets, Hayek claimed that such systems-again, neither planned nor engineered-are more complex, productive, and efficient than anything even the best and brightest human beings could devise intentionally. His is an antirationalist theory in the sense that he challenged the claim that a few smart people, using their knowledge, reason and problem-solving skills, can design a system that serves the interests of all. Only out of the chaos of spontaneous individual actions can the best social order emerge. The primary role of government, then, is not to build a just social order but rather to safeguard the right to life, liberty, and property, which will allow individuals to unleash their creative and competitive energies and, albeit unintentionally and indirectly, promote the common good.

Hayek did not claim to be the originator of this idea. He cited a number of intellectual ancestors, including Scottish enlightenment thinkers Adam Ferguson (1723-1816) and Adam Smith (1723-1790). The idea of spontaneous order features prominently in Smith, who celebrated what he saw as the self-regulating capacity of markets. In The Wealth of Nations, Smith wrote famously (or infamously) that each person who is engaged in economic life

intends only his own gain, and he is in this, as in many other cases, led by an invisible hand to promote an end which was no part of his intention. Nor is it always the worse for the society that it was no part of it. By pursuing his own interest he frequently promotes that of the society more effectually than when he really intends to promote it. I have never known much good done by those who affected to trade for the publick good. ${ }^{13}$

Without intending it at all, said Smith, self-interested individuals in the market often serve the "publick good"- and far more effectively than the dogooders who act with all the best intentions. The reference to "an invisible hand" almost smacks of divine intervention, but it's more likely that Smith was using a metaphor to illustrate the point that the public interest is usually better served, no matter how counter-intuitive or even magical it may seem, when each person cares for his own welfare.

It is crucial to note, however, that most of Hayek's intellectual ancestors, including Ferguson and Smith, did not believe that the individual pursuit of happiness automatically yielded optimal collective results. For example, Smith feared the deleterious effects that unfettered markets and the division of labor would have on public virtue, making the working class stupid and ignorant—and thus more susceptible to poor moral judgment and

12 Friedrich Hayek, Studies in Philosophy, Politics and Economics (Chicago: University of Chicago Press, 1967), 97.

13 Adam Smith, An Inquiry into the Nature and Causes of the Wealth of Nations (Oxford: Oxford University Press, 1976), 456. 
unlawful behavior. To counteract this dangerous trend, he called for statefunded education. ${ }^{14}$ Even Hayek acknowledged that government would be justified in providing "security against severe physical privation" and "a minimum sustenance for all." In a society that has achieved the level of wealth seen in developed countries, said Hayek, "there can be no doubt that some minimum of food, shelter, and clothing, sufficient to preserve health and the capacity to work, can be assured to everybody." He also saw the utility of a "comprehensive system of social insurance," arguing that "there is no incompatibility in principle between the state providing greater security in this way and the preservation of individual freedom."15 These caveats suggest that the most important thinkers in the classical liberal tradition did not see spontaneous order as an absolute truth. On the whole- "frequently," as Smith said-free markets will promote the "publick good." But when they don't, both Smith and Hayek argued, the government has a legitimate claim to make judicious corrections.

But how could Hayek square his defense of government providing economic security with his famous slippery slope argument? Quite easily. The guiding principle of his political thought - and that of Milton Friedman's, for that matter-was equality under the law. Hayek opposed public policies aimed at promoting equality of ends because such efforts necessitate treating people unequally, giving perks and privileges to the less fortunate and punishing those at the top of the socio-economic ladder with higher tax rates and other undue burdens. ${ }^{16}$ But he supported social insurance programs designed to manage risk, to guarantee some security in the event of catastrophic misfortune, because they do not violate the equality under the law principle. Everyone is covered by these programs and is entitled to their benefits should they find themselves in need of them. This explains why a true Hayekian could support universal health or unemployment insurance programs into which everyone paid equally but would disparage such policies as affirmative action and progressive taxation.

Despite the nuances in the political thought of Smith and Hayek, modern conservatives recklessly appropriate these thinkers, along with others in the classical liberal tradition, to make the claim that spontaneous order is a universal principle. In a stunning display of intellectual dishonesty, they cling to a few thinkers in the classical liberal tradition to defend their position, misread them willfully, and ignore the rest of Western political thought. On these flimsy intellectual grounds, they favor a radical agenda of dismantling the welfare state and deregulating nearly all industries (including those responsible for the recent financial crisis).

Quite cleverly, conservatives deflect attention from their own radicalism by casting liberals in this light. They often build a straw man in suggesting that proponents of reasonable government intervention in the

14 Ibid., 787-88

15 Friedrich Hayek, The Road to Serfdom (London: Routledge, 1971), 89-90. 1960), 85-102.

16 See Friedrich Hayek, The Constitution of Liberty (Chicago: University of Chicago Press, 
market favor a command economy — as if there is no difference between Lenin and Obama, between communism and liberalism. In truth, liberals do not dispute the obvious: that free markets work far better than central economic planning ever could. They merely argue that the market is a complex and occasionally flawed system. Sometimes the market fails to produce goods that society needs (e.g., affordable health care for all), while at other times it produces outcomes that society finds undesirable (e.g., pollution).

\section{IV}

Perhaps no group has a better understanding of the vicissitudes of markets than the working class. Accordingly, workers around the world have found it beneficial to organize unions and bargain collectively with their employers for higher wages, better benefits, and safer working conditions. Union membership in the United States exploded after the passage of the Wagner Act in 1935. Among other things, this law protected workers' right to organize unions, gave the newly-created National Labor Relations Board the authority to hold elections that would decide whether workers in a particular place of employment would be represented by a union, and allowed the creation of "closed shops" in which all employees in a unionized workplace are required to join the union (including those who didn't vote for it and don't want to be members). By 1954, about 35 percent of wage and salary workers in the United States were union members, thanks in large part to the Wagner Act. ${ }^{17}$ It was a time of unprecedented economic prosperity and an expanding middle class.

Much to the dismay of many liberals, unions represent only about 12 percent of wage and salary workers in America today. ${ }^{18}$ This decline stems in large part from the conservative onslaught against unions over the last thirty or more years. The hostility to public sector unions in Wisconsin, Indiana, and other states earlier this year is just the latest chapter in this story. Conservatives attack unions for a whole host of reasons-allegedly, they hurt businesses, impede economic growth, and create fiscal crises at all levels of government. But, as the recent debate illustrates, the main reason for the conservative opposition to unions rests on principle: they see mandatory membership as an infringement on economic freedom. Tim Pawlenty made this point recently in New Hampshire during a Republican presidential debate in June 2011. He expressed his support for a federal right-to-work law, which would weaken unions nationwide by making "closed shops" illegal. "We live in the United States of America," he said, "and people shouldn't be forced to belong or be a member in any organization. And the government has no business telling people what group you have to be a member of or not." ${ }^{19}$

17 Gerald Mayer, "Union Membership Trends in the United States," in Federal Publications, Paper 174 (31 August 2004), 12, <http://digitalcommons.ilr.cornell.edu/ key_workplace/174/>.

${ }_{18}$ Ibid.

19 The Republican presidential debate originally aired on CNN on June 13, 2011. 
Even if they draw the wrong conclusions from it, conservatives have a point. As Mancur Olson argues in his classic work, the survival of unions requires an element of coercion. He wrote: "By far the most important single factor enabling large, national unions to survive was that membership in those unions, and support of the strikes they called, was to a great degree compulsory." 20 Requiring workers to be dues-paying members of a union, to accept the terms of a collectively-bargained contract, and not to cross a picket line during a strike may have bolstered unions, but it certainly restricts the individual freedom to choose.

That said, Olson urges his readers to view the issue through the lens of collective action. Conservatives refuse to accept that the benefits of these coercive measures-higher wages, better benefits, and safer working conditions for the middle class-far outweigh the costs. The truth of the matter is that the vast majority of workers want these collective benefits, but if you make it easier for them to stop paying membership dues and to cross picket lines (that is, to take a free ride), unions have a much harder time staying alive. Their survival and effectiveness require coercion, argued Olson, and this is no different from any other form of coercion that societies deem necessary for the common good. For example, governments collect taxes to finance police and fire departments and enforce speed limits to keep highways safe. No one expects citizens to pay taxes or observe speed limits voluntarily. We recognize that government must use force-or the looming threat of force-to ensure widespread cooperation.

Generally speaking, democracies conform to what Abraham Lincoln called "the majority principle." The minority cannot nullify a law simply because they don't like it. Similarly, workers in a place of employment can vote in a democratic election to decide whether they want to be represented by a union. If the majority supports a union, the matter is settled. Everyone is a member and must accept the costs and benefits of what comes with this association. Rousseau believed that the best way to resolve collective action problems, such as the proverbial stag hunt, was to put it to a vote. Let the people decide whether coercive measures are necessary to ensure cooperation. The hunters in his example could have passed a law that somehow sanctioned those who abandoned their posts, thereby ensuring that the hunt would be successful and everyone would enjoy a healthy portion of venison. For the same reasons, some form of punishment awaits tax evaders, speeders, and others who fail to cooperate with laws passed by democratic majorities.

The conservative denial of collective action problems in such policy areas as consumer financial protection, health care, environmental regulation, and labor usually rests on empty appeals to "principle" and ad hominem attacks on those who call on the power of government to enforce cooperation. In January 2011, for example, Michele Bachmann made a speech on the House

20 Olson, op cit., 68. 
floor calling Obama's health care reform law "the crown jewel of socialism." 21 Even though Obamacare is hardly the equivalent of socialized medicine (which, incidentally, already exists in the United States for military personnel and veterans), Bachmann would rather score easy political points through oldfashioned red-baiting than debate the program on its practical merits.

Unfortunately, conservative high-brows are not immune to hollow invocations of principle either. About a month before the reform was passed, political philosopher Harvey Mansfield accused Obama in The Weekly Standard of trying to avert questions of "principle" and pretending that health care policy is "beyond political dispute." The "principle" at stake in Mansfield's view was the following: "Should the government take over health care or should it be left to the private sphere?"22 This is a grotesque distortion and over-simplification of the issue. The reform does not turn health care providers into government employees or restrict consumer choice of providers in the private market. Mansfield also refused to address the fact that the status quo, an unregulated private insurance system, was unsustainable. While over 46 million people lived without insurance and health care costs soared at an alarming rate, Mansfield decided to sidestep substantive matters. His strategy was to deflect attention from these inconvenient truths by engaging in erudite demagoguery, peppering his essay with ominous terms that made health care reform look like a socialist enterprise. He used "government takeover," "Big Government," and "rational administration" several times each. This kind of coded language is used to end rather than to promote discussion. After all, "Big Government" and "government takeovers" are inherently wicked-and thus political non-starters. ${ }^{23}$

It is distressing to see that "principle" has become the tool of the political obstructionist, of the apologist for the status quo. Mansfield charged Obama with affecting "the cool of a nonpartisan" and eschewing politics in his attempt to marshal the resources of the administrative state to make policy. ${ }^{24}$ He seems to have forgotten how many political compromises were made by Obama and the Democrats in order to get the law passed. The final result was a moderate - and what many have called a watered-down-reform that comes nowhere close to socialized medicine or single-payer insurance, the two most common models in the industrialized world. President Obama and the Democrats did not get what they wanted; they did what was politically feasible. Fearful of even a moderate policy solution, Republicans were uncompromising in their refusal to meet the Democrats half-way, trying to derail reform completely on so-called principled grounds.

21 Brian Montopoli, "Michele Bachmann: Health Care Law "Crown Jewel of Socialism," in cbsnews.com <http://www.cbsnews.com/8301-503544_162-20028978503544.html>, 19 January 2011.

22 Harvey Mansfield, "What Obama Isn't Saying," in The Weekly Standard 15:20 (8

February 2010), < http://www.weeklystandard.com/articles/what-obama-isnt-saying>.

${ }^{23}$ Ibid.

${ }^{24}$ Ibid. 
The only way conservatives can deny the reality of collective action problems is to dwell in a world of meaningless principle. "It is your inalienable right to leave the stag hunt should you desire," say conservatives. Never mind that most of us will go hungry as a result.

Perhaps conservatives should recall what Abraham Lincoln wrote in 1854: "The legitimate object of government, is to do for a community of people whatever they need to have done, but can not do, at all, or can not, so well do, for themselves-in their separate, and individual capacities." 25 People cannot catch stags, pay for health care, or bargain with their employers so well on their own. But they do these things remarkably well together.

Department of Political Science, Iona College, United States of America

\section{References}

Bachmann, Michele, "Giving More Power Where Power Is Not Due," in the Star Tribune (10 December 2009), <http://www.startribune.com/ opinion/79012857.html>.

Dewey, John, The Public and Its Problems (New York: Henry Holt and Company, 1927).

Ferguson, Charles, Inside Job (Sony Pictures Classics, 2010).

Gladwell, Malcolm, "The Moral-Hazard Myth," in The New Yorker (29 August 2005),

<http://www.newyorker.com/archive/2005/08/29/050829fa_fact $>$.

Hayek, Friedrich, The Road to Serfdom (London: Routledge, 1971). Studies in Philosophy, Politics and Economics (Chicago: University of Chicago Press, 1967). 1960).

, The Constitution of Liberty (Chicago: University of Chicago Press,

Hobbes, Thomas, Leviathan (New York: Penguin Classics, 1985).

Krugman, Paul, The Conscience of a Liberal (New York: W. W. Norton \& Co., 2007).

Lincoln, Abraham, "Fragments on Government," in Selected Speeches and Writings (New York: Library of America, 2009).

Madison, James, "No. 10," in the Federalist Papers (New York: Signet Classics, 2003).

Mansfield, Harvey, "What Obama Isn't Saying," in The Weekly Standard 15:20 (8 February 2010), <http://www.weeklystandard.com/articles/whatobama-isnt-saying $>$.

Mayer, Gerald, "Union Membership Trends in the United States," in Federal Publications, Paper 174 (31 August 2004), <http://digitalcommons.ilr. cornell.edu/key_workplace/174/>.

25 Abraham Lincoln, "Fragment on Government," in Selected Speeches and Writings (New York: Library of America, 2009), p. 91. 
Montopoli, Brian, "Michele Bachmann: Health Care Law 'Crown Jewel of Socialism," in cbsnews.com < http://www.cbsnews.com/8301503544_162-20028978-503544.html>, 19 January 2011.

Olson, Mancur, The Logic of Collective Action (Cambridge, MA: Harvard University Press, 1965).

Rousseau, Jean-Jacques, The Basic Political Writings (Indianapolis: Hackett Publishing Company, 1987).

Smith, Adam, An Inquiry into the Nature and Causes of the Wealth of Nations (Oxford: Oxford University Press, 1976).

Woolhandler, Steffie, Terry Campbell, and David Himmelstein, "Costs of Health Care Administration in the United States and Canada," in The New England Journal of Medicine 349:8 (21 August 2003).

World Health Organization, World Health Statistics 2011,

<http://www.who.int/whosis/whostat/2011/en/index.html>. 